\title{
CO-CREATING HEALTHCARE CAMPAIGNS THROUGH DESIGN AND SOCIAL MARKETING APPROACHES
}

\author{
Edson Coutinho Da Silva \\ University Centre FEI, São Bernardo do Campo, Brazil.
}

Silvio Augusto Minciotti

Municipal University of São Caetano do Sul, São Paulo, Brazil

\begin{abstract}
This theoretical article aims to present and describe the role of the design thinking approach, and social marketing canvas model in designing and improving an action plan for a healthcare campaign addressed to target audiences exposed to a disease, such as COVID-19. The latest global events encouraged this author to produce and write this essay to introduce two agile instruments for co-creating and co-producing a healthcare campaign considering the citizen experience. The design approach and social marketing canvas are based on agile methodologies and lean principles to reach two primary results: (a) design, co-create and co-produce a 'social product/service'; (b) social marketing canvas co-organises the strategies required to address the 'social product/service' to a target audience. Furthermore, both tools have the role of inducing a social change by policymaking in healthcare campaigns in a humanised way and considering the individuals as the primary agents of social change.
\end{abstract}

KEYWORDS: design, innovation, social marketing, social change, social marketing canvas.

\section{INTRODUCTION}

Since December 2019, a new virus called the severe acute respiratory syndrome coronavirus 2 (SARS-CoV-2) has been identified as the cause of a disease outbreak in Wuhan province, China. The disease is named coronavirus disease 2019 (COVID-19). Because this virus is so new, not much is known about it yet. Public health organisations, such as the World Health Organisation (WHO) and the United States Centre for Disease Control and Prevention (CDC), are investigating. The new coronavirus appears to be spreading from person to person. It may be spread by respiratory droplets when someone infected with the virus coughs or sneezes. It is unclear exactly how contagious the virus is (WHO, 2020; CDC, 2020). However, according to WHO Coronavirus (COVID-19) Dashboard, until 18 January 2022, 326.279,424 confirmed cases, 5.536.609 deaths were confirmed and 9.395.059.118 vaccines doses were administered in 223 countries globally (WHO, 2022).

In general, COVID-19 symptoms can be mild to severe and include a fever, cough and shortness of breath. Symptoms may appear 2 to 14 days after exposure. Unfortunately, a coronavirus vaccine is not currently available. Thus, WHO (2020), as well as CDC (2020), recommend that individuals take the usual precautions for avoiding respiratory viruses, such as (a) wash the hands often with soap and water or use an alcohol-based hand sanitiser; (b) cover the mouth and nose with an elbow or a tissue when he/she coughs or sneezes; (c) avoid touching the eyes, 
nose and mouth if the hands are not clean; (d) avoid close contact with anyone who is sick; (e) clean surfaces he/she often touches; (f) and stay home from work, school and public areas if he/she is sick. Since January 2020, these organisations have been promoting healthcare campaigns based on these recommendations. However, the success of a healthcare campaign depends on valuable tools to encourage people to consider ideas and behaviours to induce a social change. Overall, two instruments can assist health policymakers in improving a healthcare campaign, such as COVID-19 disease: design thinking approach and social marketing principles.

Recently, the relevance of citizens engagement and how designing with and for citizens impact the efficiency and quality of campaigns are the two key drivers that have to be considered. They play an essential role in a successful campaign (Junginger, 2017). If the co-creation in consumption does not work, it causes significant problems and dissatisfaction not only for citizens but also for the public (or non-profit) organisations. Currently, campaigns should be co-created because distinct stakeholders and, critically, individuals are involved in innovating approaches.

In such a way, working together, understanding the way citizens recognise the campaigns, how they get involved and how they appreciate the campaigns' benefits as a driver for changes (Roberts et al., 2016). The incorporation of citizens or "end-users" view in problem definition is observed to enable a richer understanding of the problem and direct attention to a more distinction solution. Even the best and most expensive campaigns can fail if they neglect the citizens' perspective; hence, design thinking approaches emerge as a crucial instrument to improve campaigns (Trischler, Dietrich \& Rundle-Thiele, 2019). Likewise, a healthcare campaign cannot produce the expected outcomes in setting up media as the unique alternative to encourage behavioural changes in target audiences. Health organisations tend to focus on media tools and information instead of individuals' social change processes. The social change processes happen when a target audience identifies and recognises the benefits of changing (Silva \& Mazzon, 2018).

Thus, Social Marketing principles arise as another helpful tool for assisting health organisations in planning and carrying out campaigns. The goal is a voluntary change for preventing diseases, for instance, COVID-19. Then, how to design a humanised healthcare campaign driven to a given disease using design thinking approaches and social marketing principles based on a canvas model for supporting it? Therefore, this theoretical paper aims to present and describe the role of design thinking practices and the social marketing canvas model for designing and improving an action plan (healthcare campaign) addressed to target audiences exposed to a disease.

\section{Design Approach}

Design approaches are at the heart of this emerging landscape of contemporary innovation, often functioning as the enabling factor in driving a social change in campaigns. So it is, not least, because the design changes the perspective and mindset of public (or non-profit) entities at policymaking. There are four arguments for encouraging design, as a practice: (a) management outcomes, systematic focus on the practical results of public interventions for the 
citizens that healthcare campaign exists for; (b) citizen engagement, closing the gap between public sector entities and people and enabling a deeper understanding and appreciation of the daily lives of citizens; (c) systems thinking abilities to establish interventions with a holistic awareness of the interconnections and complexity of health issues; (d) prototyping skills to test, pilot and enhance promising ideas rapidly to examine and learn about what sort of initiatives will serve people best. (Futurs Publics, 2017; Mintrom \& Luetiens, 2016; Trischler, Dietrich \& Rundle-Thiele, 2019). In effect, design thinking enabling user-centred and creative exploration of new possibilities and learning-oriented experimentation and operationalisation of healthcare campaigns seem to be better suited for dealing with health problems, as COVID-19, in the current social environments and policymaking contexts.

The challenge of the design approach is to optimise the results with the experience, without false choices or engagements. The design practice aims to broaden the notion of campaign scope to improve and deliver benefits to citizens. However, things do fail, and when professionals do, it is not good if citizens are subject to all types of inconveniences and additional burdens, which are monetary similar to penalties and surcharges (Arundel, Bloch \& Ferguson, 2019). There are two barriers which design practices need to deal with in the public (or non-profit) entities: first, speed and pace action, these organisations on the whole work at a slightly slower pace and other stakeholders have to adjust; secondly, these entities require a lot more internal and stakeholder commitment. Overall, some authors argue that design approaches in the healthcare campaigns are often restrained by public health systems, religious statutes, distinct cultures, political systems, health regiments, and even regulatory elements that can limit the capacity of exploration as well as the viability of potential responses (Blomkamp, 2008; Junginger, 2017; Kimbell, 2015).

Generally speaking, the design approach aims to share a clear vision to achieve goals and benefits in a given campaign. By and large, the design technique encompasses five key steps from problem definition to 'prototype' test, see figure 01: step 1 includes track the health problem according to primary stakeholders; step 2 aims to analyse and understand the health problem, context and available information building an empathy map with citizens - 'personas' - carrying out ethnographic research; step 3, after empirical research, health professionals make decisions to sketch and address the best solution for the health problem according to a given locality or target audience; step 4 refers to design and organise a healthcare campaign 'prototype' to carry over the best results; step 5 encompasses citizens testing, asking to them the most compelling questions to review and make sense of the feedback (Kimbell, 2015; Mintrom \& Luetiens, 2016; Roberts et al. 2016).

The ultimate step delivers a 'social product/service' - a vital component for the social marketing canvas - resulting from a healthcare campaign seamlessly aligned to citizens' perceptions and experience. Hence, in the design approaches for healthcare campaigns, the front-stage is where results and experiences accomplish through various touchpoints and interfaces, so it designs for behaviours and communications, for example, COVID-19 campaign recommendations, so it all plays out well, just promised (Blomkamp, 2018). 


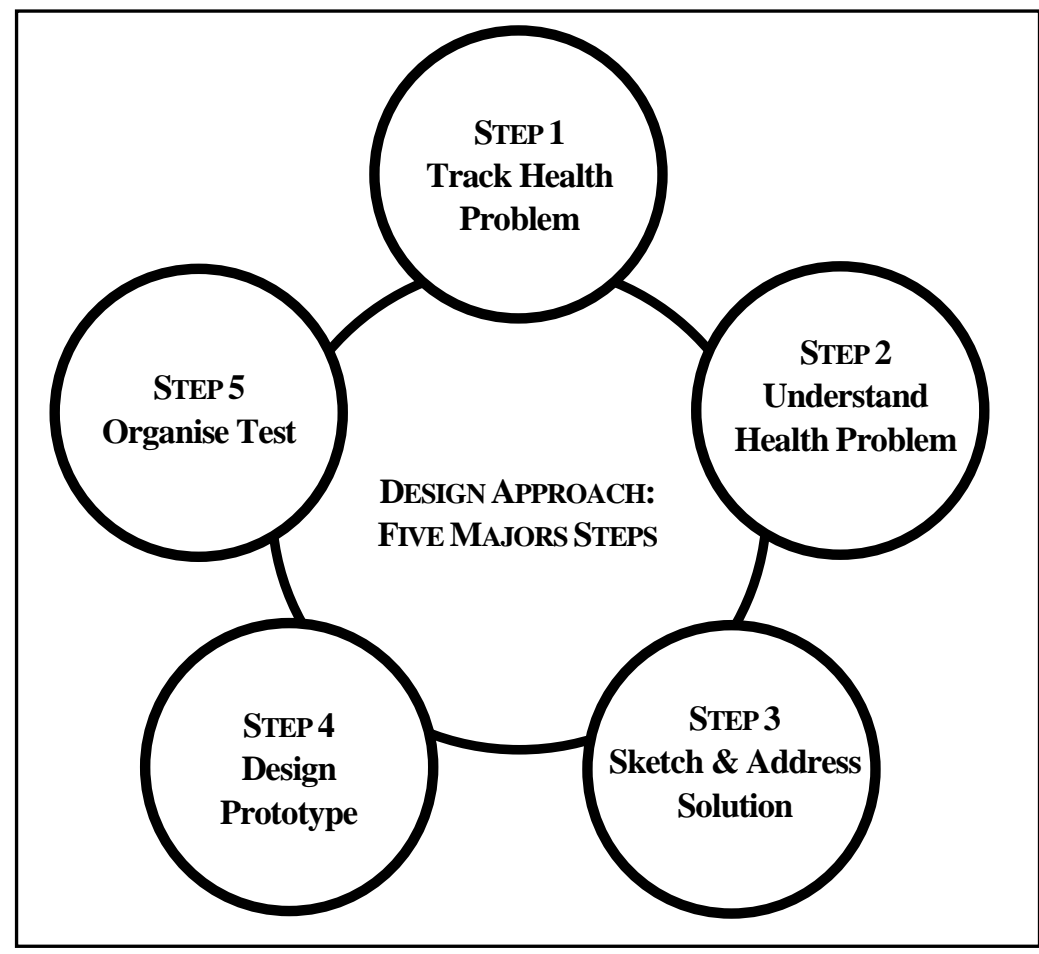

Figure 1: Five Major Steps of Design Approach

Source: Service Design Network (2016) and OECD (2015)

The orientation change focuses on individuals at the centre of public problems, and policy solutions are the two key drivers of a design approach. The main argument for the value of design in healthcare campaigns is that it can modify the perspective of public policies and healthcare campaigns from a supply-oriented logic into a demand-oriented and people's centre view (Roberts et al., 2016). Design can change the way healthcare campaigns are designed and implemented to meet citizens' needs and reconnect the government with citizens. Still, it can also transform how healthcare campaigns are planned and delivered by public and non-profit entities.

Furthermore, the design method can assist policymakers in putting the citizens and their communities at the core of the analysis of disease symptoms to design and carry out an appropriate campaign (Futurs Publics, 2017). Shergold (2015) states that design can go beyond problem-solving when creating a healthcare campaign with better connecting supply and demand. It can make public policies more desirable, compelling and delightful, creating new experiences for citizens with the potential of impacting perceptions, behaviour and choice, all three vital elements of the role of policies as inductors of social change. Thus, this change in orientation complements the traditional top-down policy approach with a bottom-up 
perspective, considering citizens as the primary agents of social change, allowing them to become co-creators and co-producers of healthcare campaigns.

\section{Social Marketing Canvas}

Social marketing is a marketing application created by Kotler and Zaltman (1971) driven to design, implementation and monitor social or health programmes to intervene and influence the acceptability of social or health ideas to solve a social problem through marketing strategies and activities. For Kotler \& Roberto (1989), social marketing uses ideas as to value proposition, to create, modify and maintenance behaviours. Then, ideas are the 'remedies' to encourage and engage new attitudes to overcome social problems - or causes. Thus, social change is the core and goal of social marketing. On the one hand, according to Silva \& Mazzon (2018), unlikely any other sort of Marketing, the concept of exchange in social marketing from a healthcare campaign involves intangible goods as well-being and quality of life; besides, the benefits are not immediate.

On the other hand, social marketing focuses on promoting social justice, reducing social inequalities and supporting citizens to reach the happiest and healthiest life. Social marketing designs ideas that evoke social change. For Kotler \& Roberto (1989), social change is an organised effort by a given entity to influence people to accept, adhere, alter and reject certain ideas, recommendations, attitudes, customs and behaviours to solve a social problem.

Overall, social marketing programmes aim to improve healthcare campaigns when the changing behaviour is the goal. This is because target audiences are most exposed to social or health problems (Gordon, Russell-Bennett \& Lefebvre, 2018). Then using COVID-19 as a reference, the target audience the most exposed are those travelling through countries or areas where there are plenty of individuals who were or are infected with the coronavirus.

However, there are critical elements for social marketing programmes achieve the expected results in a healthcare campaign (Lefebvre, 2011; Silva \& Mazzon, 2016; Smith \& Strand, 2009): (a) fit a social marketing model to the programme objectives as well as country emergence; (b) select and manage key actors for supporting the marketing activities to deliver the social product/service to a target audience; (c) plan and carry out marketing research to ensure a right, convenient and organised social marketing programme reach the audience; (d) establish the social change process to design essential and attractive benefits to reach target audience needs; (e) select and determine the message and media most suitable to the audience; (f) co-create and co-organise a social marketing programme as well as, encompass target audience testing to reach the most efficient and effective healthcare campaign according to citizens' view. 
British Journal of Marketing Studies Vol. 10, Issue 1, pp.1-12, 2022 Print ISSN: 2053-4043(Print),

Online ISSN: 2053-4051(Online)

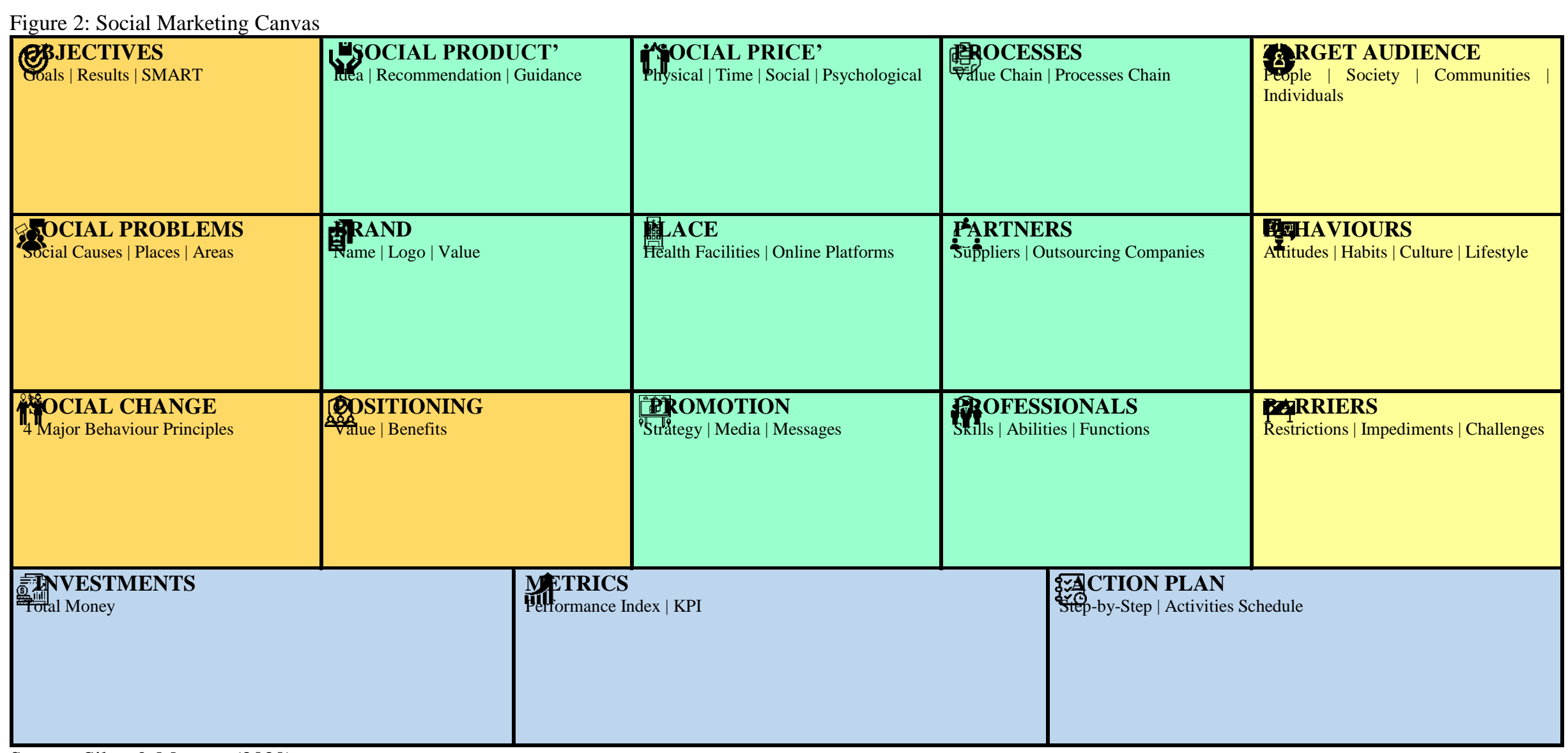

Source: Silva \& Mazzon (2020) 
To use the social marketing principles, enhance effectiveness and achieving the best results in healthcare campaigns. Silva and Mazzon (2016) introduced a conventional social marketing plan described in three major axes: diagnosis, benefits, social change, and marketing mix. Three years later, these same authors organised another social marketing model but used the canvas platform to describe a social marketing programme (Silva \& Mazzon, 2020).

The social marketing canvas is a powerful instrument to assist social marketers in understanding a social marketing plan in a straightforward and structured manner. Using this canvas will lead to insights into the purpose of the campaign, target audience, and the most appropriate marketing mix and investments and metrics, just summarising some essential information (Silva \& Mazzon, 2016). This social marketing canvas is organised in four fundamental axes: target audience (yellow colour), the purpose of the campaign (orange colour), marketing mix (green colour) and marketing control (blue colour). These authors recommends exactly this sequence for developing a social marketing canvas model (Silva \& Mazzon, 2020). Figure 02 and the description of the key components will be presented below.

\section{Yellow colour}

- The target audience represents a small group from the population who share common attributes: geography, demographics, perceptions, media channel, etc. This audience must reflect the 'personas' from the design approach and share the same marketing mix. Therefore, one marketing mix for each target audience and never on a single marketing mix for all groups. - Behaviours refer to previous and current behaviours from a target audience, such as attitude, motivation, lifestyle, values, etc. Cismaru, Lavack \& Sievers (2017) state that social marketers must identify and analyse the 'harmful' or dangerous behaviours to design social change processes afterwards.

- Barriers are determinant impediments or restrictions of which professionals work on to overcome. External barriers are the forces outside the individual, for instance, professionals' skills, service quality, bureaucracy, ethnicity and religious values, lifestyle, etc. Internal barriers are forces inside an individual's head that affect how he/she thinks or feels about behaviour, such as knowledge, attitudes, self-efficacy, future intention behaviour, perceived social norms, perceived consequences (Smith \& Strand, 2009).

\section{Orange colour}

- Objectives are the goals and results. They must: be lined up to the social change in one or more levels; measurable; represent the performance goals and results those entities want to attain in a healthcare campaign; be specific, have a date and location; be goals realistic; be clear; start with an infinitive verb, because it is an action; be known by all stakeholders (Silva \& Mazzon, 2016).

- Social problems encompass a social cause, for example, a disease (COVID-19), cancer prevention, tobacco, alcohol, child obesity, etc. These problems impact citizens' well-being and financial costs for the public sector (Kotler, 1975).

- Social change happens when a transformation changes the previous or current state of any social reality, for instance, changing behaviour, attitude, value, lifestyle, etc. Two theories support the social change levels. First, Kotler (1975) introduces four levels: cognition, action, behaviour, and value in this order. Then, Prochaska \& DiClemente (1983) present a sequence 
based on six stages: pre-contemplative, contemplative, preparation or decision-making, action, maintenance, and termination. In summary, either theory is appropriate to design a social change (Silva \& Mazzon, 2016).

- Positioning aims to reach the citizens' mind (cognition) and, then, make them think and reflect about the 'new' alternatives of change means, focusing on attractive benefits and values to overcome barriers in their mind (Cismaru, Lavack \& Hill, 2009).

\section{Green colour}

- The social product/service is the 'prototype' resulting from the design approach (Junginger, 2017). In effect, a social product/service is intangible as it is an idea, behaviour, action, orientation, recommendation, prevention, or treatment (Firestone et al., 2017). Thus, all the guidance provided by WHO (2020) and CDC (2020) to prevent COVID-19 disease should be a social product/service. Nonetheless, those pieces of advice were produced after symptoms were evidenced in a particular group of individuals in China. Therefore, this work should be compared to 'design thinking work'.

- Social price represents all costs involved in a concept of change, for instance, physical, time, social and psychological costs. Price requires renouncing the impediments and restrictions; and waiving the pleasure, amusement, social events, etc. Generally speaking, the cost encompasses barriers that a target audience 'pay' to overcome (Silva \& Mazzon, 2016).

- Place means where, when and how social products/services are available for a target audience. Place approaches the physical and online distribution channels. Due to intangibility, social products/services can be accessed everywhere. However, some healthcare campaigns provide tangible products (condoms, pills, etc.) and intangible products (medical exams, medical appointments, etc.). Therefore, some places should be arranged in either case, such as hospitals, health centres, popular pharmacies, schools, and the Internet (Ministry of Health's website, social networks, etc.)

- Promotion is the most popular tool among health professionals. Communication aims to persuade citizens to reflect and balance the costs and benefits of change. Promotion requires understanding the target audience and media habits to define the content of messages, communication approaches and media. The goal is to achieve the individuals' minds in seeking two results: positioning the campaign benefits and ensuring a sustainable and healthy relationship between public or non-profit entities and target audience.

- Processes are visible and non-visible activities to produce healthcare campaigns. A poorly designed process chain can create a slow, bureaucratic and ineffective delivery and, consequently, it should cause dissatisfaction to a target audience under service quality perspective. On the other hand, processes well-designed add value and increase performance to product/service and should be co-created together with citizens and crucial partners and stakeholders (Russel-Bennett, Previte \& Zainuddin, 2009).

- Partners represent suppliers and outsourcing organisations that develop, manage and support activities through the process chain. Pharmaceutical laboratories, hospitals (private and public), research and media agencies, transport, logistic and technology companies, non-profit and governmental organisations, governments, etc., are examples of partnership in a healthcare campaign.

- Professionals are crucial to get outstanding performance in a healthcare campaign. According to the target audience, the staff team represents the quality of service. Then, the 
Vol. 10, Issue 1, pp.1-12, 2022

Print ISSN: 2053-4043(Print),

Online ISSN: 2053-4051(Online)

skills, commitments, engagements and responsibilities can make the difference in a given healthcare campaign. Nevertheless, provide support, consistent infrastructure, guidelines, training, etc. In effect, skills in health programmes and campaigns, social marketing and Innovation (Design) are essential to managing a healthcare campaign for a target audience.

\section{Blue colour}

- Investments correspond to the total money and resources needed to design, implement, and control the healthcare campaign. Ordinarily, public and non-profit organisations are the two primary sponsors of a healthcare campaign. However, private organisations can also finance, provide funds or become co-sponsor of a healthcare campaign (Silva \& Mazzon, 2020).

- Metrics are key performance indexes that social marketers establish. These metrics can encompass, for instance, the numbers of individuals who 'bought' the benefits of the campaign, the number of citizens who were informed about the campaign, the number of people who changed their behaviour, etc. In summary, metrics depict the campaign status, goals and success (Henley, Raffin, Caemmerer, 2011).

- The action plan aims to describe the sequence of activities required to execute and monitor the campaign step by step. In addition, this action plan serves stakeholders as a project schedule to report when the task will carry out, how long it will be concluded and who will be responsible for ensuring the performance and results of the healthcare campaign (Silva \& Mazzon, 2020).

\section{Final Considerations}

This theoretical paper aimed to present and describe the function of design practice and social marketing canvas for designing and improving a healthcare campaign addressed to target audiences exposed to a disease, for instance, COVID-19. This author aimed to introduce and address two agile frameworks to healthcare campaigns to assist public and governmental managers in dealing with complex health problems. Since the 2000 s the agile methodologies and lean management have been a constant agenda when private companies. On the one hand, agile methodology is a practice that promotes continuous interaction of development and testing the product development lifecycle of a project.

On the other hand, lean management is an approach to manage projects using the concept of continuous improvement to achieve small and incremental changes in processes to improve the efficiency and quality of products/services (Junginger, 2017). Design thinking practices are an agile methodology because this tool invites users, customers and stakeholders to co-create a solution (product/service) for themselves. Also, the design approach is based on lean practices since social marketers 'learn by doing' and 'learn by sharing' over five steps to deliver the best solution possible to individuals. Nevertheless, design thinking is not only for private companies. Since 2010, plenty of studies have been developed and published considering design thinking in the public sector to provide and deliver better services to citizens. Improvement of public transport, social and health programmes are the major projects that have been developed using design thinking practices. Australia, France, Scandinavian countries and the United States have used design techniques to improve policymaking (Blomkamp, 2018; Futurs, Publics, 2017; Kimbell, 2015; Mintrom \& Luetiens, 2016; Shergold, 2015). Unlike the private sector, the public sector and non-profit organisations have not implemented design thinking for profits but 
for creating policymaking to deliver social products/services more suitable for individuals, for instance, healthcare campaigns, such as COVID-19 disease.

Thus, the result of design thinking processes is a 'social product/service' or a healthcare campaign (Junginger, 2017). Then, the next step involves organising a social marketing canvas to lean the 'social product/service' to a target audience. Thus, the first two squares that social marketers need to fill are 'social product' and target audience. The following steps are, in this order, completing yellow, orange, green and, finally, the blue squares (Silva \& Mazzon, 2020). Overall, design thinkers focus on creating a product/service (healthcare campaign) and social marketers works on fitting and driving it to a target audience.

Regardless of issues concerning economic, political and social, public and governmental organisations are required to produce more agile responses and fewer bureaucratises to deal with complex problems and situations. The design approach encompasses a core methodology that includes practices for citizen research, solution and experience mapping, value creation, design and prototyping and a broader approach to social problems, which is collaborative, human-centred, data-driven, interaction and multidimensional (Trischler, Dietrich \& RundleThiele, 2019).

Social marketing is an alternative to create a customer-citizen-orientation backed to integrated marketing to generate citizen satisfaction as the key to behaviour change in a healthcare campaign (Gordon, Russell-Bennett, Lefebvre, 2016). Overall, social marketing focuses on optimising public resources as long as it works in health instead of disease. Therefore, both design techniques and social marketing require a partnership and relationship with citizens and society to co-conceive, co-design and deliver benefits for both and achieve the goals of a healthcare campaign, that is, individuals' quality of life and well-being.

This author wants to encourage and instigate researchers to develop new empirical studies integrating public health, innovation, and social marketing in healthcare campaigns from this theoretical paper.

\section{References}

Arundel, A.; Bloch, C. \& Ferguson, B. (2019). Advancing Innovation in the Public Sector: Aligning Innovation Measurement with Policy Goals. Research Policy, 48, 789-798.

Blomkamp, E. (2018). The Promise of Co-Design for Public Policy. Australian of Public Administration, 77(4), 729-743.

Centers for Disease Control and Prevention - CDC (2020). COVID - 19. Coronavirus Disease. What you need to know about Coronavirus Disease 2019 (COVID-19) (2020, 10 March). Retrieved from: https://www.cdc.gov/coronavirus/2019ncov/downloads/2019-ncov-factsheet.pdf

Cismaru, M., Lavack, A. M. \& Hill, P. J. (2009). Social Marketing Campaigns Aimed at Preventing drunk driving. International Marketing Review, 26(3), 292-311.

Firestone, R.; Rowe, C. J.; Modi, S. N. \& Sievers, D. (2017). The Effectiveness of Social Marketing in Global Health: A Systematic Review. Health Policy and Planning, 32(1), 110-124. 
Futurs Publics (2017). French Manifesto for Public Sector Innovation: A New Approach to Public Policy-Making. Premier Ministre: Secrétariat Général pour la Modernisation de l'Action Publique (2019, November 16). Retrieved from: https://www.modernisation.gouv.fr/sites/default/files/french_manifesto_for_public_ sector_innovation.pdf

Gordon, R.; Russell-Bennett, R. \& Lefebvre, R. C. (2016) Social Marketing: The State of Play and Brokering the way Forward. Journal of Marketing Management, 32(11-12), 1059-1082.

Henley, N., Raffin, S. \& Caemmerer, B. (2011). The Application of Marketing Principles to a Social Marketing Campaign, Marketing Intelligence \& Planning, 29(7), 697-706.

Junginger, S. (2017) Design Research and Practice for the Public Good. Reflection. The Journal of Design, Economics, and Innovation, 3(4), 290-302.

Kimbell, L. (2015). Applying Design Approaches to Policy Making: Discovering Policy Lab. Brighton: University of Brighton.

Kotler, P. \& Roberto, E. L. (1989). Social Marketing Strategies for Changing Public Behavior. London: Collier Macmillan.

Kotler, P. \& Zaltman, G. (1971), Social Marketing: An Approach to Planned Social Change, Journal of Marketing, 35, 3-12.

Kotler, P. (1975). Marketing for Non-profit Organisations. Englewoods Cliffs, New Jersey: Prentice-Hall.

Lefebvre, R. G. (2011). An integrative Model for Social Marketing, Journal of Social Marketing, 1(1), 54-72.

Mintrom, M. \& Luetiens, J. (2016). Design Thinking in Policymaking Processes: Opportunities and Challenges. Australian Journal of Public Administration, 75(3), 391-402.

Prochaska, J. O. \& DiClemente, C. C. (1983). Stages and Processes of Self-change of Smoking. Toward and Integrative Model of Change. Journal of Consulting and Clinical Psychology, 51, 390-395.

Roberts, J. P.; Fisher, T. R.; Trowbridge, M. J. \& Bent, C. (2016). A Design Thinking Framework for Healthcare Management and Innovation. Healthcare, 4, 11-14.

Russel-Bennett, R., Previte, J. \& Zainuddin, N. (2009). Conceptualising Value Creation for Social Change Management. Australasian Marketing Journal, 17(4), 211-218.

Shergold, P. (2015). Learning from Failure: Why Large Government Policy Initiatives Have Gone So Badly Wrong in the Past and How the Chances of Success in the Future Can be Improved. Canberra: Australian Public Service Commission.

Silva, E. C. \& Mazzon, J. A. (2016) Developing Social Marketing Plan for Health Promotion. International Journal of Public Administration, 39(8) 577-586.

Silva, E. C. \& Mazzon, J. A. (2018) Revisitando o Marketing Social. Brazilian Journal of Marketing - BJM, 17(6), 806-820.

Silva, E. C. \& Mazzon, J. A. (2020) Planejamento de Marketing Social: Uma Aplicação para Adesão de Mulheres nas Campanhas de Saúde da Região do ABC Paulista. In: Lee, N. R. \& Kotler, P. Marketing Social: Influenciando Comportamentos para o Bem. São Paulo: Saraiva. 
British Journal of Marketing Studies

Vol. 10, Issue 1, pp.1-12, 2022

Print ISSN: 2053-4043(Print),

Online ISSN: 2053-4051(Online)

Smith, W.A. \& Strand, J. (2009). Social Marketing Behavior: A Practical Resource for Social Change Professionals. Washington, DC: Academy for Educational Development (AED).

Trischler, J., Dietrich, T. \& Rundle-Thiele, S. (2019). Co-Design: From Expert to UserDriven Ideas in Public Service Design. Public Management Review, 21(11), 15951619.

World Health Organization - WHO (2020). Advice on the use of Masks the Community, during Home Care and in Health Care settings in the context of the novel Coronavirus (2019-nCoV) Outbreak. Interim guidance 29 January 2020. (2020, 08 March). Retrieved from: https://www.who.int/docs/default-source/documents/advice-on-theuse-of-masks-2019-ncov.pdf

World Health Organization - WHO (2022). WHO Coronavirus (COVID-19) Dashboard (2022, January 18). Retrieved from: https://covid19.who.int/ 